Research Article

\title{
Experimental and Application Study on Underpinning Engineering of Bridge Pile Foundation
}

\author{
Lei Yan $\mathbb{D},{ }^{1}$ Gang Wang, ${ }^{1}$ Min Chen, ${ }^{1}$ Kefeng Yue, ${ }^{1}$ and Qingning Li $\mathbb{D}^{2}$ \\ ${ }^{1}$ School of Civil Engineering, Chongqing Three Gorges University, Wanzhou, Chongqing 404020, China \\ ${ }^{2}$ School of Civil Engineering, Xi'an University of Architecture and Technology, Xi'an, Shaanxi 710055, China \\ Correspondence should be addressed to Lei Yan; yanlei1988413@163.com
}

Lei Yan and Gang Wang contributed equally to this work.

Received 2 August 2018; Revised 1 November 2018; Accepted 8 November 2018; Published 4 December 2018

Academic Editor: Belén González-Fonteboa

Copyright $(92018$ Lei Yan et al. This is an open access article distributed under the Creative Commons Attribution License, which permits unrestricted use, distribution, and reproduction in any medium, provided the original work is properly cited.

In order to study the theory and application of the pile foundation underpinning technology, 3 local node models of underpinning structures with a similarity ratio of $1 / 1$ were made and the progressive repeated static loading tests were conducted. The shear and antislip properties of the joint are studied, and the improved formula for calculating the shear capacity is proposed. The results show that a planting bar plays a major role in shear resistance, and the hoop rate can improve the shear capacity of the interface. The new formula for calculating the shear-bearing capacity is proposed, and the calculation results of the formula of shear-bearing capacity are in good agreement with the experiment results. It is completely feasible to use this formula to calculate the shearbearing capacity of the pile foundation underpinning structure. During the test, the bearing capacity of the model is good, which proves the reliability of the underpinning technology is good, and it can provide experimental and theoretical basis for the underpinning of similar projects.

\section{Introduction}

Pile underpinning technology can not only effectively protect existing buildings but also solve the problems of urban transportation and underground space construction [1-6]. In the process of strengthening the early Winchester Cathedral, the submersible workers used the underwater digging technology to reach the gravel layer after crossing peat and silt and then filled it with concrete to carry out the underpinning construction [7]. After World War II, the pile underpinning technology was applied in many German projects, and a series of theoretical research studies were carried out, and the underpinning technology was listed as its industrial standard [8]. Underpinning construction was adopted on line 9 of the Berlin subway so that the subway tunnel can be constructed normally [9]. In the Swedish Imperial Palace, built in the middle of the eighteenth century, the side hall inclines due to the wood pile foundation and uneven thickness foundation soil, and the effect was remarkable after the pile foundation underpinning method was selected [10]. An active underpinning technology was adopted in Kyoto Metro Station of Japan, and the underpinning structure could meet the design requirements by controlling the settlement of piles [11].

The underpinning technology in China started relatively late, but with the massive construction of the national infrastructure, the number and scale of underpinning projects continue to grow. The underpinning technology was used for the first time on line 1 of the Guangzhou subway; in addition, the underpinning technology was adopted in the construction process of Guangzhou subway lines 2-6 [12]. On the basis of a large number of theoretical and experimental research studies, the active underpinning technology is used to cross the department store, and the implementation of a real-time monitoring technology in the process of construction has been used to ensure the reliability of the project [13]. The Cheng-Mian-Le Passenger Dedicated Railway which cuts through the Expressway 
Elevated Bridge of Airport and underpins the two piers, respectively, in the form of "two piles to support a cap" [14]. The single-span integral girder was used to underpin two piers in the bridge of the Shenzhen subway cut through Guangzhou-Shenzhen Railway, and the train continued operation during the underpinning construction [15].

In summary, the current pile underpinning technology mostly relies on construction experience, but the theoretical and experimental studies are relatively few. The specification for the underpinning technology of our country has not yet been formally promulgated. At present, the design of the underpinning structure is fully referred to the relevant design specifications of the concrete structure, but the study on the shear calculation model and the practical formula of the concrete structure is relatively few, only the semitheoretical and semiempirical formulas. Based on this, the truss-arch model is used to analyze the shear-bearing capacity of the underpinning structure, and the correctness and reliability of the proposed formula are verified by the comparison of the theoretical and experimental results. Through the research of this paper, we hope to provide experimental and theoretical support for similar projects.

\section{Engineering Description}

The practical project (Figure 1) is a concrete continuous beam bridge with a different shape located in the west of China. Its girder is made of concrete with the width of $15.25 \mathrm{~m}-35 \mathrm{~m}$ and the total length of $75 \mathrm{~m}$ and composed of four continuous units with a span arrangement of $22.569 \mathrm{~m}+$ $5.529+22.107 \mathrm{~m}+22.936 \mathrm{~m}$. The section of the pier which would be underpinned is $2.5 \mathrm{~m} \times 1.3 \mathrm{~m} \times 10 \mathrm{~m}$. A pier cap under the pier is $6.5 \mathrm{~m}$ long, $6.5 \mathrm{~m}$ wide, and $2 \mathrm{~m}$ high. Four piles with a diameter of $1.5 \mathrm{~m}$ and height of $35 \mathrm{~m}$ were under the cap.

According to the specific parameters of the underpinned structure, the size of the prestressed concrete underpinning structure is $20.3 \mathrm{~m}$ long, $8.7 \mathrm{~m}$ wide, and $3.5 \mathrm{~m}$ high, respectively. C50 waterproof concrete is used in the underpinned structure. The regular reinforcement is HRB335, and the prestressed reinforcement adopts a high-strength and low-relaxation steel strand, whose tensile strength standard $\left(f_{\mathrm{py}}\right)$ value is $1860 \mathrm{MPa}$ and modulus of elasticity $\left(E_{\mathrm{P}}\right)$ is $195 \mathrm{GPa}$. The diameter of the underpinning pile is $2 \mathrm{~m}$, and the pile length is $73 \mathrm{~m}$ and $64 \mathrm{~m}$. In addition, the strength of the concrete is C30. The size of the concrete underpinning structure is shown in Figure 2.

\section{Experimental Design}

3.1. Model Design. In this paper, a local $1: 1$ joint model of the underpinning beam and existing bearing platform connection was studied. Three specimens were designed, numbered $\mathrm{J}-1, \mathrm{~J}-2$, and $\mathrm{J}-3$, respectively. The concrete strength of the existing cap in the local model is C35, and the diameter of the steel bar is $16 \mathrm{~mm}$. In the local model, 8 HRB335 steel bars with a diameter of $25 \mathrm{~mm}$ were adopted by the connecting beam and the existing cap.

The strength of the dragging beam is C50, and HRB335 ribbed bars with a diameter of $\Phi 32 \mathrm{~mm}$ were used for

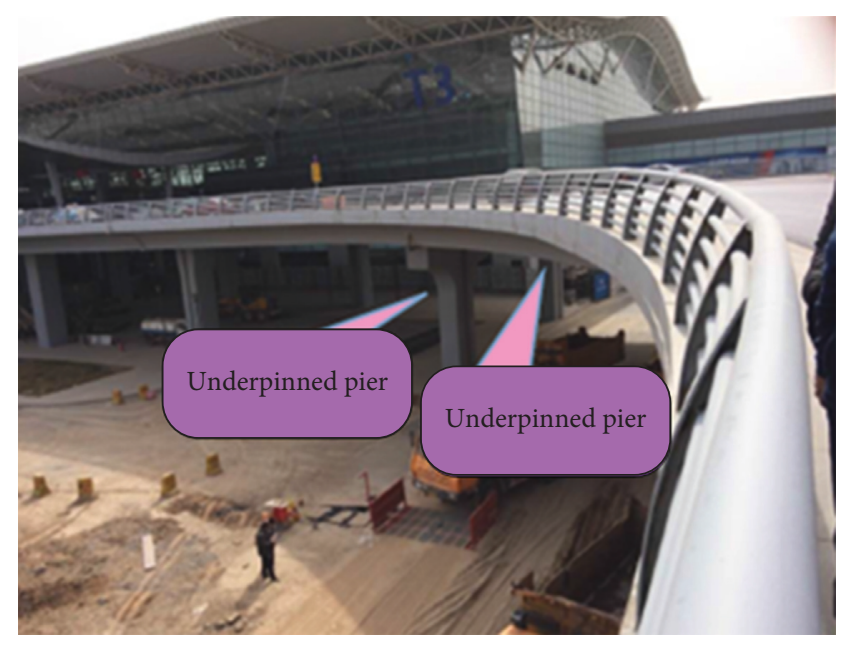

FIGURE 1: Underpinned pier.

longitudinal reinforcement. The diameter of the stirrup of specimens J-1 and J-2 is $8 \mathrm{~mm}$, and the diameter of the stirrup of J-3 is $10 \mathrm{~mm}$. The spacing between stirrups is $50 \mathrm{~mm}$. The specific size and reinforcement of the underpinning beam are shown in Figure 3. The specimens are shown in Figure 4.

The specific parameters of the three specimens after completion are shown in Table 1.

3.2. Material Tests. The bearing platform and underpinning beam are built two times. The strength of the bearing platform concrete is $\mathrm{C} 35$, the strength of the underpinning beam concrete is C50, and the steel bar HRB335 was used. The mechanical properties of the materials are shown in Tables 2 and 3.

In conclusion, the performance of concrete and steel bars can satisfy the experimental requirements.

3.3. Experimental Design. The 2000T microcomputercontrolled electrohydraulic servo compression shear test machine was adopted in this experiment. The loading accuracy is $50 \mathrm{kN}$, and the length of the test machine is $5 \mathrm{~m}$, which can meet the loading requirement of this test. The test system is composed of displacement meters and resistance strain gauges. The data on sensors are measured by the static data acquisition system. The loading device and the acquisition system are shown in Figure 5.

During the loading process, each specimen was tested by the progressive cycle mode. The specimens are loaded before and after yield, respectively, according to the load and displacement control style. When the load control style was used, the $150 \mathrm{kN}$ repeated loading test was carried out two times: at first, $200 \mathrm{kN}$ was taken as the load in the first stage and repeated loads to $3000 \mathrm{kN}$ were applied next; after that, cyclic loading was applied at the $100 \mathrm{kN}$ level until the specimen was yielded. After yielding, the maximum displacement value $\delta$ of the specimen is given; thereafter, the load was loaded at the $0.5 \delta$ level, and each stage was repeated 3 times until the specimen was destroyed. 


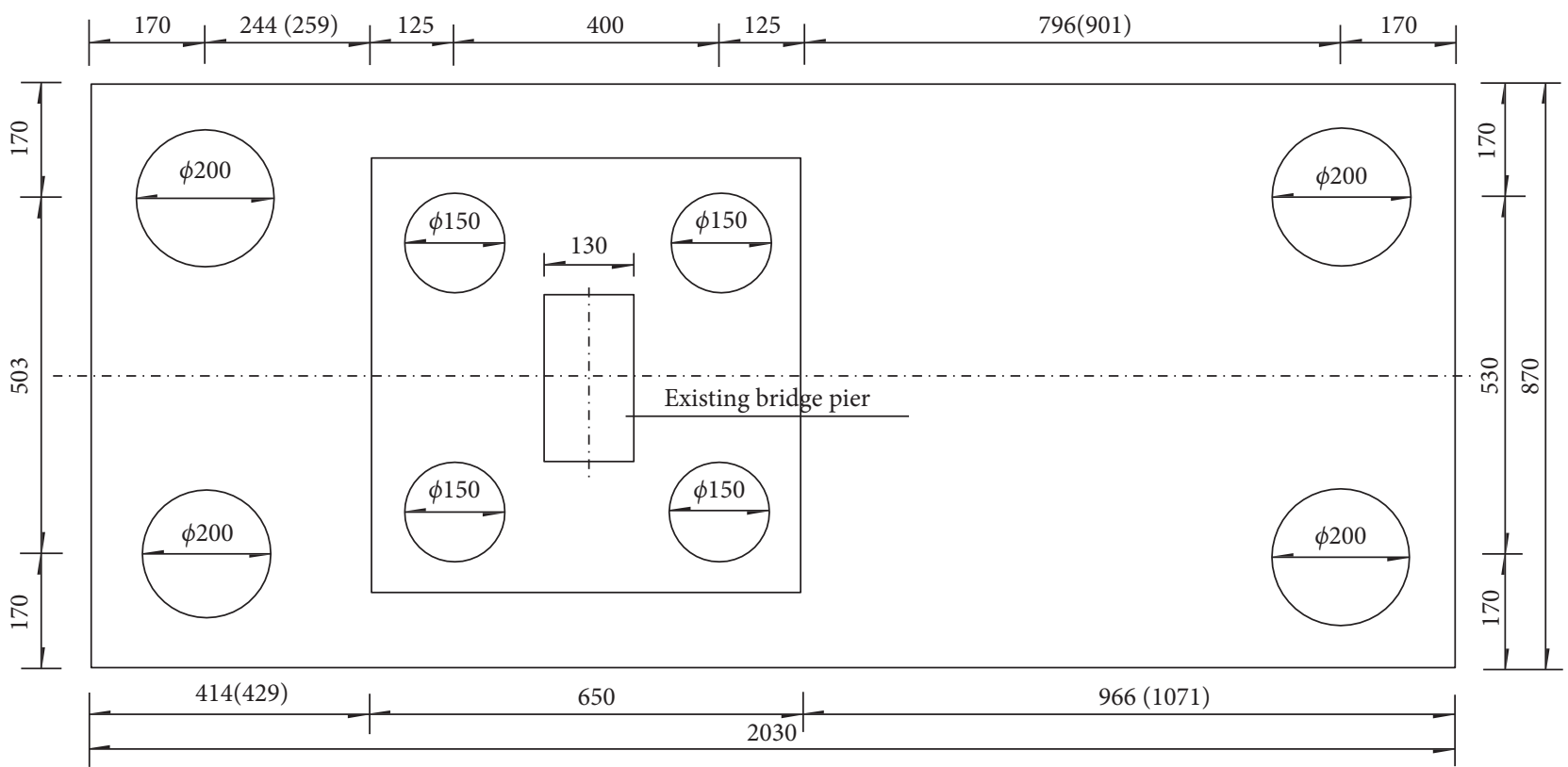

(a)

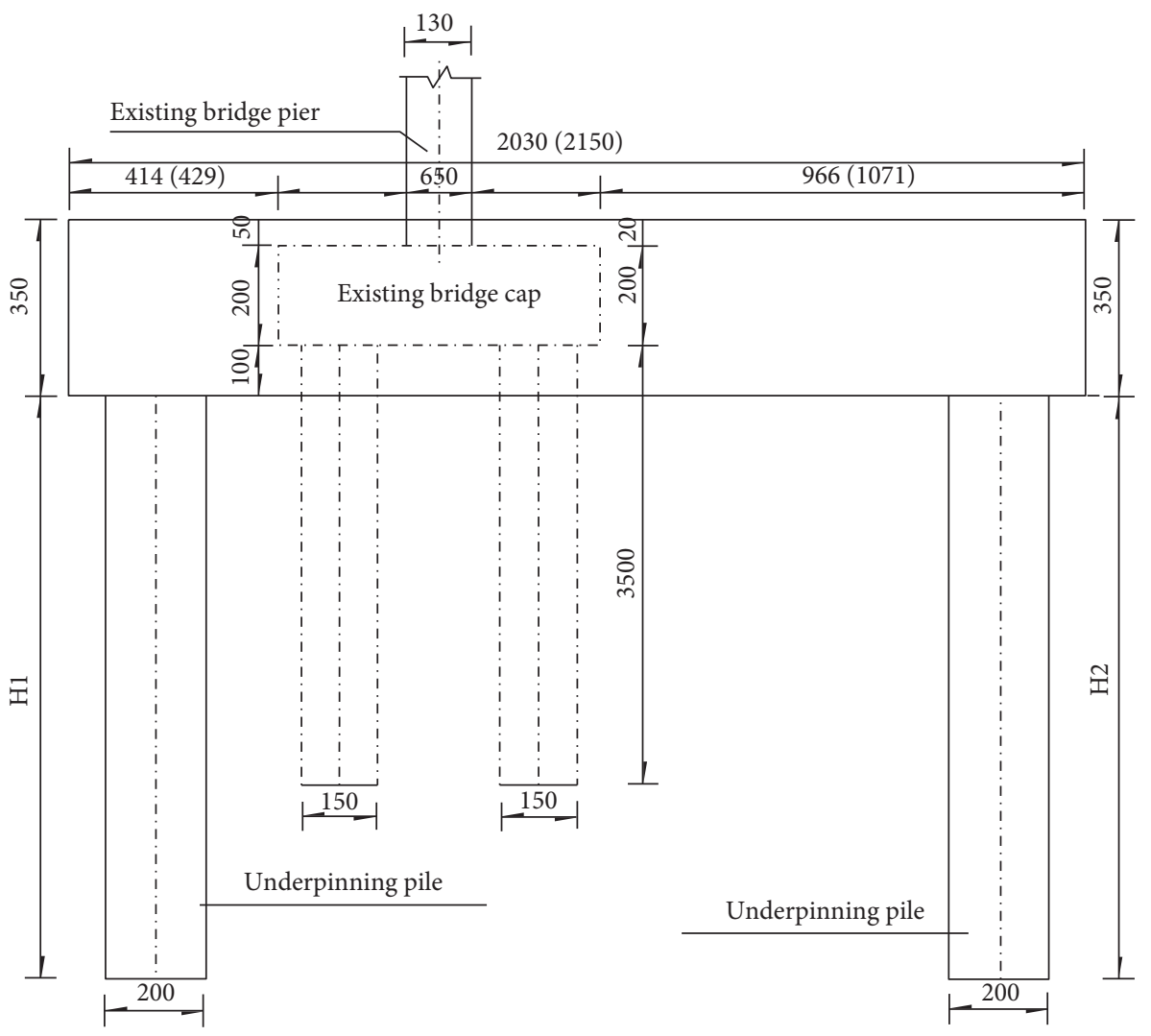

(b)

FIgURE 2: Underpinning structure. (a) The plane diagram and (b) longitudinal section diagram of the underpinning beam (unit: $\mathrm{m}$ ).

The main contents are steel strain, concrete strain, and vertical deformation. Strain gauges were arranged on the steel bar and concrete surface (Figures 6 and 7). Displacement sensors were arranged in the vertical direction of the specimen (Figure 8).

\section{Analysis and Study on Experimental Phenomena}

4.1. J-1 Specimen. At the initial stage of loading, the load control was adopted. When the load was increased to 


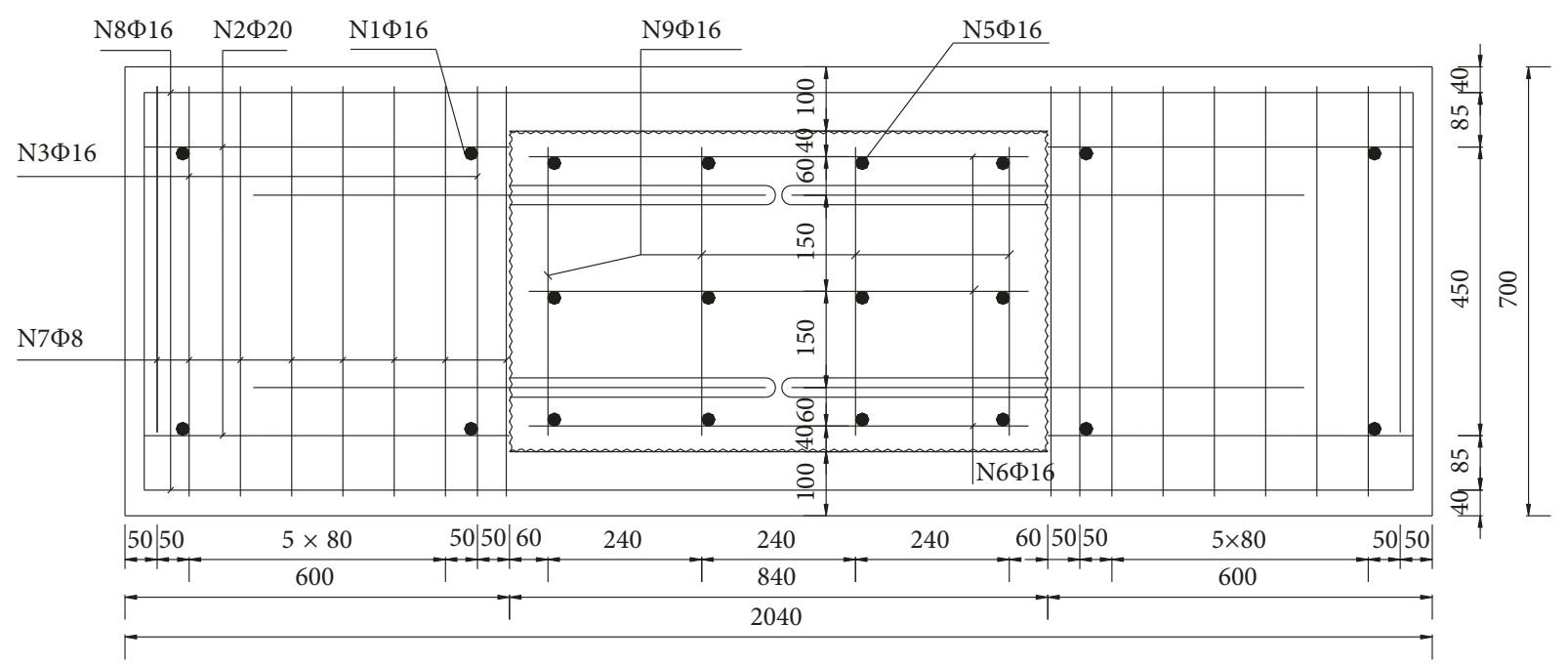

(a)

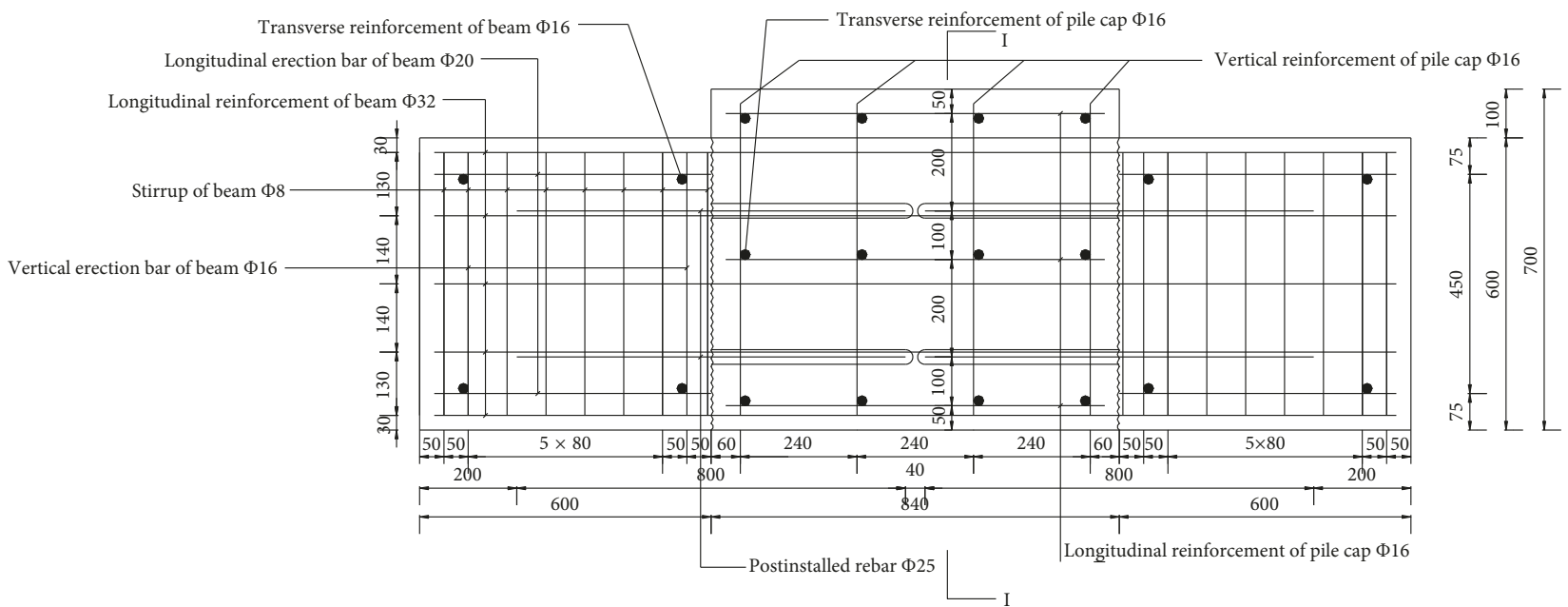

(b)

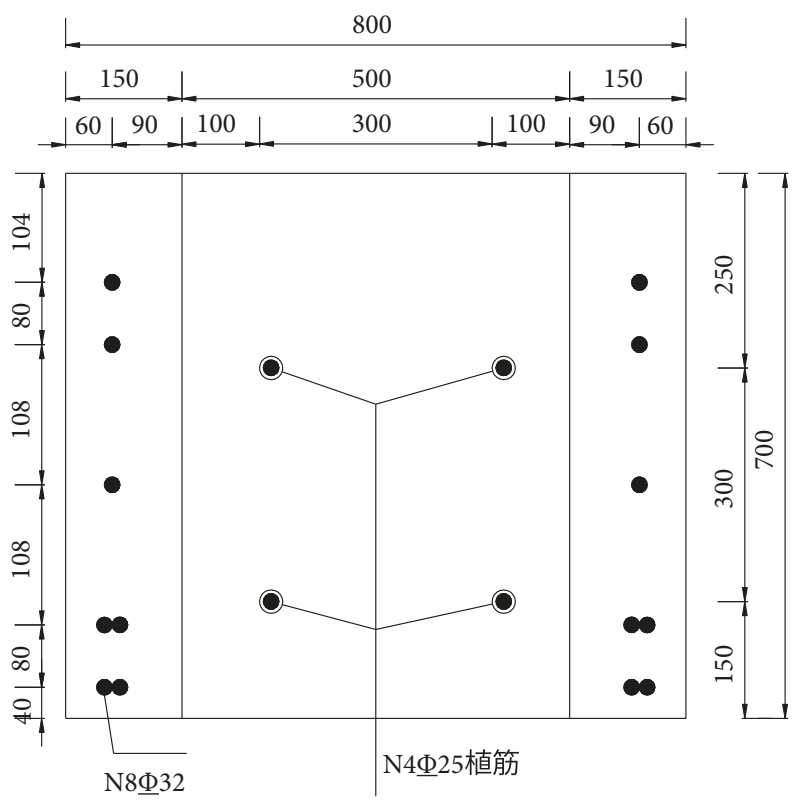

(c)

FIGURE 3: The size and reinforcement of the underpinning beam. Reinforcement assembly of the (a) plane and (b) longitudinal section (unit: $\mathrm{cm})$. (c) I-I section. 


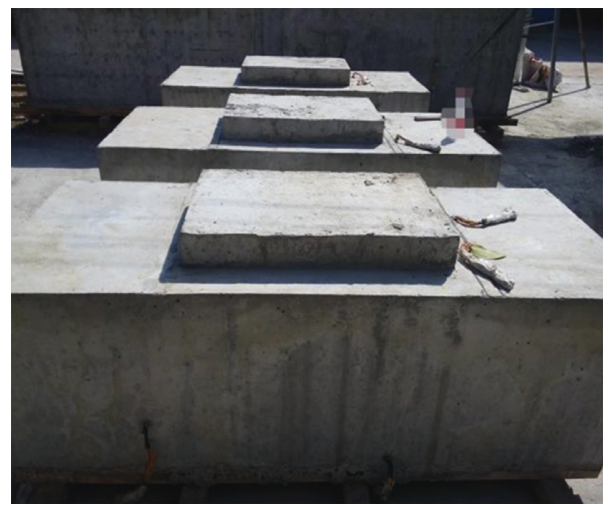

FIgURE 4: Experimental specimens.

TABLE 1: Size of the specimen and diameter of stirrups.

\begin{tabular}{lcccccc}
\hline $\begin{array}{l}\text { Test } \\
\text { specimen }\end{array}$ & $\begin{array}{c}\text { Span of the beam } \\
(\mathrm{mm})\end{array}$ & $\begin{array}{c}\text { Height of the beam } \\
(\mathrm{mm})\end{array}$ & $\begin{array}{c}\text { Width of the beam } \\
(\mathrm{mm})\end{array}$ & $\begin{array}{c}\text { Cross section size } \\
\left(\mathrm{mm}^{2}\right)\end{array}$ & $\begin{array}{c}\text { Cap height } \\
(\mathrm{mm})\end{array}$ & $\begin{array}{c}\text { Diameter of stirrups } \\
(\mathrm{mm})\end{array}$ \\
\hline $\mathrm{J}-1$ & 2040 & 600 & 800 & $840 \times 500$ & 700 & 90 \\
$\mathrm{~J}-2$ & 2040 & 600 & 800 & $840 \times 500$ & 700 & $\Phi 8$ \\
$\mathrm{~J}-3$ & 2040 & 600 & 800 & $840 \times 500$ & 700 & $\Phi 8$ \\
\hline
\end{tabular}

TABle 2: Mechanical properties of steel bars.

\begin{tabular}{lcccc}
\hline Steel bars & $\begin{array}{c}\text { Yield } \\
\text { strength } \\
(\mathrm{MPa})\end{array}$ & $\begin{array}{c}\text { Ultimate } \\
\text { strength } \\
(\mathrm{MPa})\end{array}$ & $\begin{array}{c}\text { Elongation } \\
(\%)\end{array}$ & $\begin{array}{c}\text { Modulus of } \\
\text { elasticity } \\
(\mathrm{MPa})\end{array}$ \\
\hline $\begin{array}{l}\text { Experimental } \\
\text { data }\end{array}$ & 346 & 463 & 6.1 & $2 \times 10^{5}$ \\
\hline
\end{tabular}

$700 \mathrm{kN}$, there were a number of transverse cracks at the interface between the new and old concrete at the bottom of the specimen, the length of the crack was up to $8 \mathrm{~cm}$, and the width of the crack was up to $0.1 \mathrm{~mm}$. When the load was increased to $800 \mathrm{kN}$, the crack at the bottom of the specimen continued to develop to the side, the crack length was up to $12 \mathrm{~cm}$, and the maximum width of the crack was up to $0.2 \mathrm{~mm}$. Since then, before the load reaches $1200 \mathrm{kN}$, with the increase of load, the number of vertical cracks increases, and the length and width of original cracks increase. Starting from $1200 \mathrm{kN}$, the diagonal cracks appeared between the support and the loading point, and with the increase of load, vertical cracks and diagonal cracks alternated. When the load was increased to $2000 \mathrm{kN}$, the partial stirrups began to yield and the maximum width of cracks was $0.5 \mathrm{~mm}$. Thereafter, the displacement control was adopted, and there was a big cracking sound when the vertical displacement reached $4.6 \mathrm{~mm}$. When the displacement was loaded to $5.04 \mathrm{~mm}$, the loading force reached $3750 \mathrm{kN}$, the load had a short stoppage, and there was internal force redistribution of the structure. When the loading force reached $5343 \mathrm{kN}$, the loading force no longer increased and the specimen was severely cracked and destroyed. The specific form of destruction is shown in Figure 9.

4.2. J-2 Specimen. At the initial stage of loading, the load control was adopted. When the load was increased to $700 \mathrm{kN}$,
TABle 3: Mechanical properties of concrete.

\begin{tabular}{lcc}
\hline Strength grade of concrete & C35 & C50 \\
\hline Average value $(\mathrm{MPa})$ & 37.1 & 53.41 \\
Standard value $(\mathrm{MPa})$ & 29.2 & 43.74 \\
Test conclusion & \multicolumn{2}{c}{ Strength conforms to } \\
& \multicolumn{2}{c}{ requirements } \\
\hline
\end{tabular}

there were multiple transverse cracks at the interface between the new and old concrete at the bottom of the specimen. When the load was increased to $800 \mathrm{kN}$, the bottom cracks developed to the side, forming multiple vertical fractures, the length of the crack was up to $6 \mathrm{~cm}$, and the width was up to $0.1 \mathrm{~mm}$. When the load was increased to $1200 \mathrm{kN}$, the number and length of vertical cracks increased significantly. There were more diagonal cracks between the loading point and the bearing, after the load started from $1200 \mathrm{kN}$.

When the load was increased to $2100 \mathrm{kN}$, the maximum width of the crack was up to $0.6 \mathrm{~mm}$. Thereafter, the displacement control was adopted. When the displacement was loaded to $5.92 \mathrm{~mm}$, the loading force reached $5706 \mathrm{kN}$, the load had a short stoppage, and there was internal force redistribution of the structure. When the loading force was increased to $5343 \mathrm{kN}$, the loading force no longer increased, a large number of horizontal and oblique cracks appeared in the bottom of the beam, and the specimen was severely cracked and eventually destroyed. The specific form of destruction is shown in Figure 10.

4.3. J-3 Specimen. The loading method of J-3 is the same as that of J-2. When loading force was increased to $800 \mathrm{kN}$, there were multiple transverse cracks at the interface between the new and old concrete at the bottom of the specimen, the maximum length of the crack was $10 \mathrm{~cm}$, and the maximum width was $0.15 \mathrm{~mm}$. When the load was increased to $1000 \mathrm{kN}$, the cracks at the bottom expanded to the 


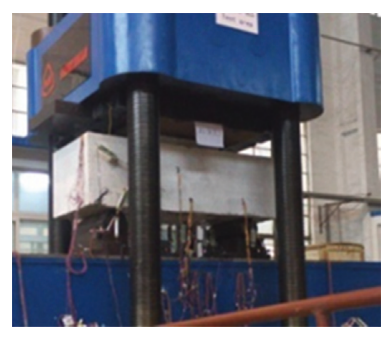

(a)

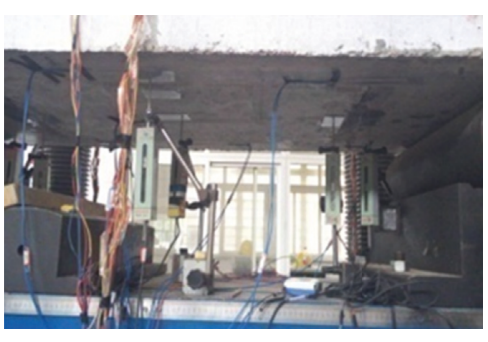

(b)

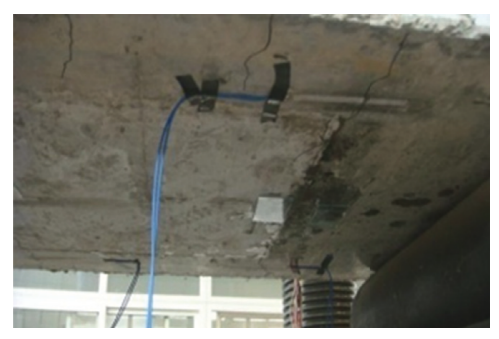

(c)

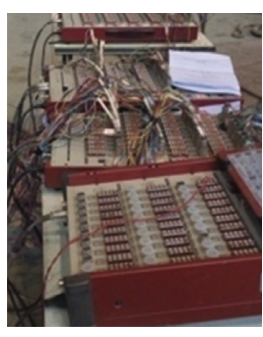

(d)

FIgURE 5: (a) Loading device; (b) displacement meters; (c) strain gauges; (d) static data acquisition system.

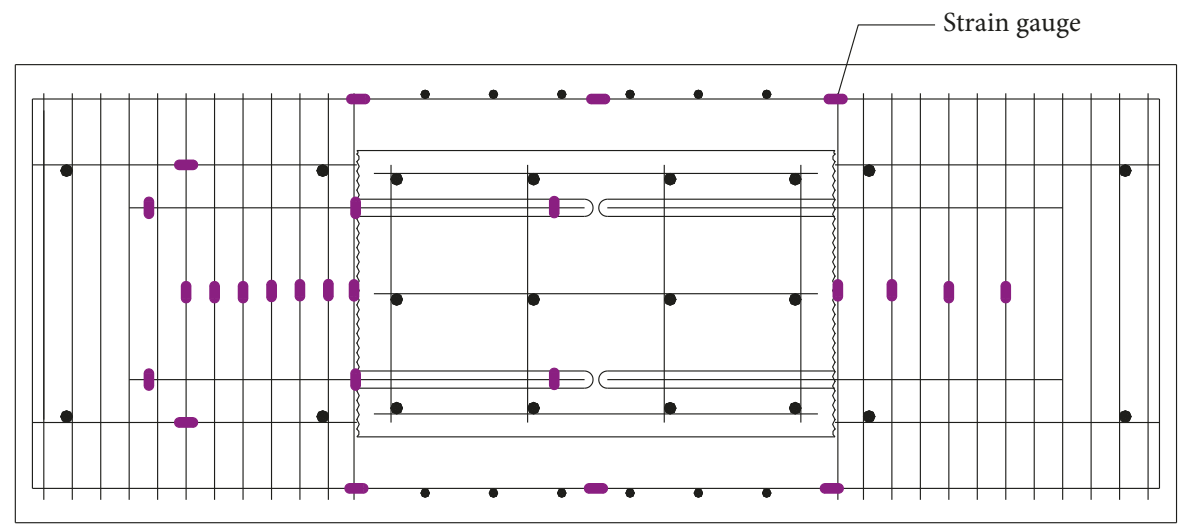

FIGURE 6: Layout of strain gauges in the longitudinal steel bar.

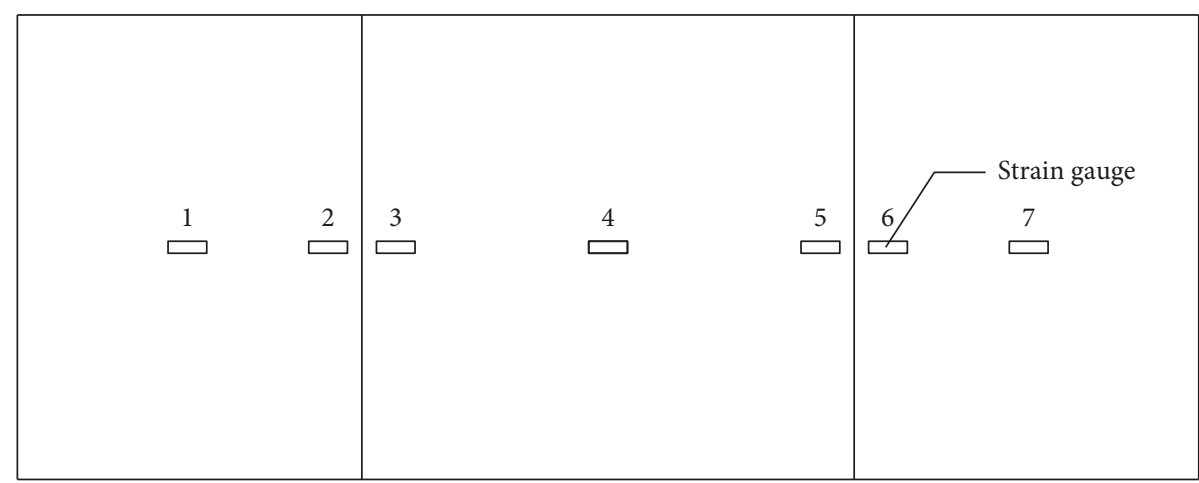

FIGURE 7: Layout of strain gauges in the concrete surface.

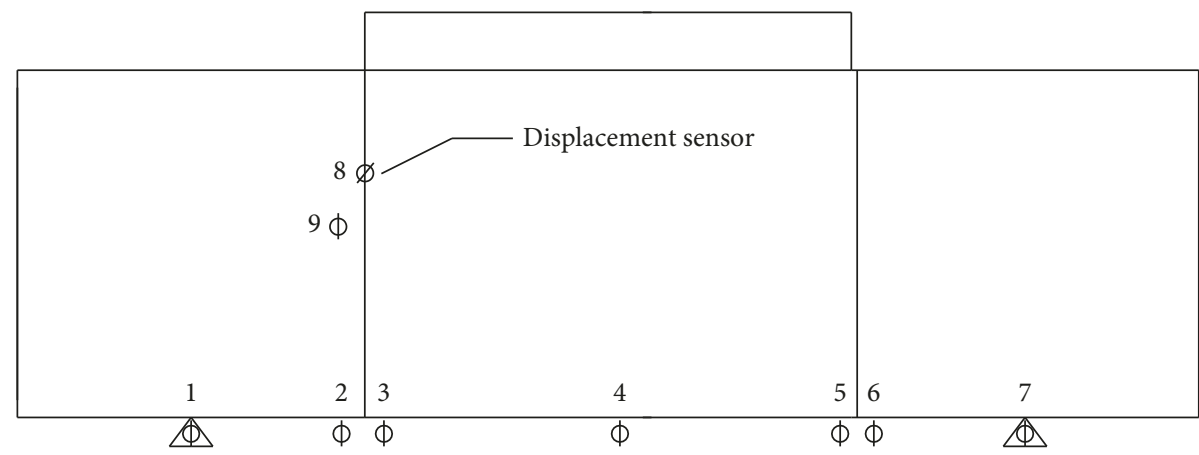

FIGURE 8: Layout of displacement sensors in the specimen. 
side to form vertical cracks, and the longest crack reached $30 \mathrm{~cm}$. From the beginning of $1600 \mathrm{kN}$, there was a slanting crack between the loading point and the bearing; the number, length, and width of the cracks increased in varying degrees with the increase of load. When the load was increased to $3700 \mathrm{kN}$, the maximum width of the crack was up to $0.6 \mathrm{~mm}$.

After that, the displacement control was adopted. When the maximum load was increased up to $7098 \mathrm{kN}$, there were many transfixion cracks at the bottom of the beam, the oblique cracks were more and more wide, and there were interlaced cracks at each end of the specimen. With the increase of loading displacement, the load value no longer increased, but the maximum displacement of the beam bottom reached $9.0 \mathrm{~mm}$. Finally, the specimen was damaged. The form of destruction is shown in Figure 11.

\section{Experimental Result}

5.1. The Deformation Curve of Each Point of the Specimens. Figures 12-14 show the measuring points deformation of different specimens. The analysis results show that the relative deformation of the 3 specimens at the initial stage of loading was relatively small. With the increase of load, the displacement difference between new and old concrete gradually increased, which indicated the vertical slip between new and old concrete. By analyzing the data from the whole loading process, we can see that the maximum sliding volume of the three specimens is $2.72 \mathrm{~mm}$, $3.03 \mathrm{~mm}$, and $1.38 \mathrm{~mm}$, respectively.

\subsection{Analysis of Bearing Capacity and Failure Form.} Figure 15 shows the relationship between deflection and load of specimens. It can be seen from Figure 15 that, at the initial stage of loading, the load displacement curve of each specimen was basically linear, the specimen was in the elastic stage, and the initial stiffness of the specimen was large and the deformation was small. Before the load was increased to $5343 \mathrm{kN}$, the slippage of the J-1 specimen increased with the increase of load, but then the midspan deflection did not increase with load. The load was loaded after $5343 \mathrm{kN}$, and then the load did not continue to increase, but the deflection continues to increase, indicating that the specimen J-1 was damaged when the load was increased to $5343 \mathrm{kN}$, and the load value is the ultimate load of the specimen. Similarly, J-2 and J-3 specimens are destroyed at $5706 \mathrm{kN}$ and $7098 \mathrm{kN}$, respectively.

It can be seen from the relationship between midspan deflection and the load of the 3 specimens that the deflection load curve of J-1 and J-2 specimens is very close. When J-3 is compared to J-1 and J-2, the load value added for the same deflection value is less than that of J-1 and J-2, and the main reason for the above phenomenon is that the stirrup diameter of the J-3 specimen is $10 \mathrm{~mm}$, while the stirrup diameter of the J-1 and J-2 specimens is $8 \mathrm{~mm}$. Therefore, the stirrup ratio of the specimen has a greater influence on the bearing capacity of the structure, and the greater the stirrup ratio, the greater the stiffness of the specimen. The bearing capacity and cracks of the three specimens are compared and analyzed. The failure modes of the specimens of J-1, J-2, and J-3 were all splitting failure through the development of the cracks in the test parts and the ultimate fracture direction and width. The bearing capacity and failure modes of the specimens are shown in Table 4.

5.3. Strain Analysis of Stirrups. Figure 16 shows the relationship between the stirrup strain and load of the J-1 specimen, and the stirrups were numbered from left to right. It can be seen from Figure 16 that the stirrup does not produce excessive strain before $1000 \mathrm{kN}$, which is not obviously involved in resisting load. With the increase of the load, the strain increases on the stirrups, gradually exerting antishear action. Through the numerical analysis, it is found that the stirrup at the interface between the old and the new concrete is first involved in the work, and then the stirrups on both sides of the interface work in turn.

The relationship between the stirrup and the load in Figure 17 (J-2 specimen) and Figure 18 (J-3 specimen) is basically the same as that of the J-1 specimen. When the load reaches $1000 \mathrm{kN}$, the stirrup is involved in the work, and the yield load of the stirrup is $3500 \mathrm{kN}$ and $4500 \mathrm{kN}$, respectively. Figure 19 shows the strain curves of the first yielding stirrup of 3 specimens with load variation as well. It is also seen that the load increases from the beginning of the $1000 \mathrm{kN}$ stirrup strain.

5.4. Strain Analysis of Longitudinal Bar. Figure 20 shows the longitudinal bar strain curve of the J-1 specimen. From the diagram, the strain rate of longitudinal reinforcement and concrete is less than that of $1200 \mathrm{kN}$ before loading. At $1200 \mathrm{kN}$, the stress of the specimen was redistributed and the change rate of the lower longitudinal reinforcement strain increased, which indicated that the concrete at the bottom of the specimen was cracked, the concrete near the longitudinal reinforcement was out of work, only the longitudinal reinforcement was pulled, and the stress of the longitudinal reinforcement increased, as well as the strain. When the load was increased to $4500 \mathrm{kN}$, the lower longitudinal bars yield, and the specimen was not damaged at this time.

Figure 21 shows the longitudinal bar strain curve of the $\mathrm{J}-2$ specimen. From the diagram, it can be seen that the strain rate of the longitudinal reinforcement and the concrete is less than that of the concrete before $1000 \mathrm{kN}$ loading. At $1000 \mathrm{kN}$, the stress of the specimen is redistributed and the change rate of the lower longitudinal reinforcement strain increases, which indicates that the concrete at the bottom of the specimen is cracked, the concrete near the longitudinal reinforcement is out of work, only the longitudinal reinforcement is pulled, the stress of the longitudinal reinforcement increases, and the strain increases. When the load is $4000 \mathrm{kN}$, the longitudinal bars at the bottom of specimen appear yield and the specimen is not damaged at this time. 


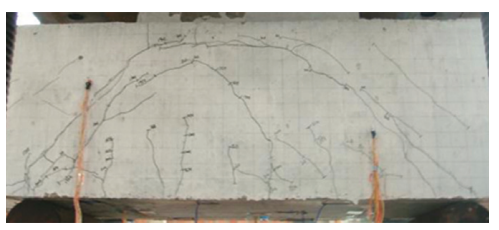

(a)

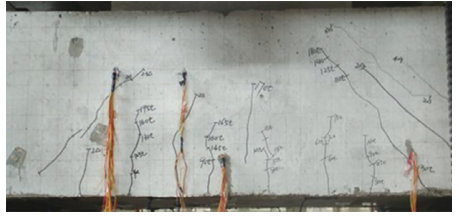

(b)

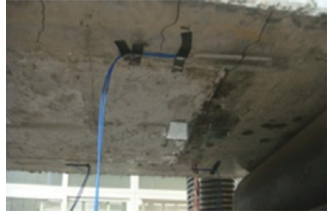

(c)

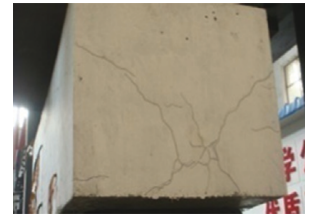

(d)

Figure 9: Main destruction of J-1 on the south side (a), on the north side (b), at the bottom of the specimen (c), and on the west side (d).

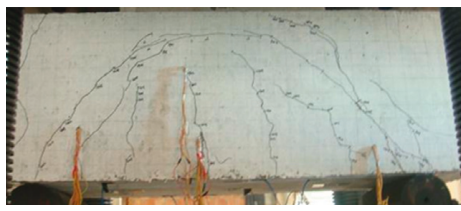

(a)

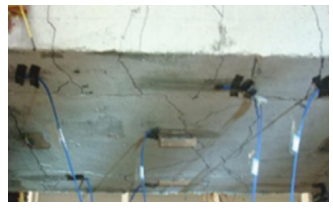

(c)

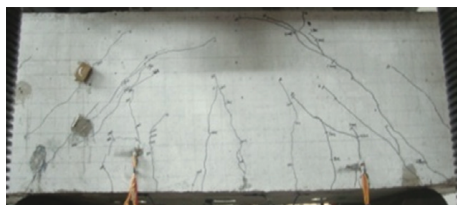

(b)

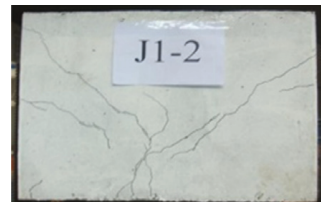

(d)

Figure 10: Main destruction of J-2 on the south side (a), on the north side (b), at the bottom of the specimen (c), and on the west side (d).

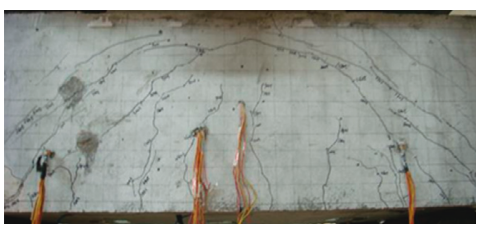

(a)

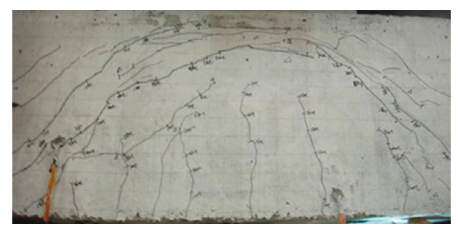

(b)

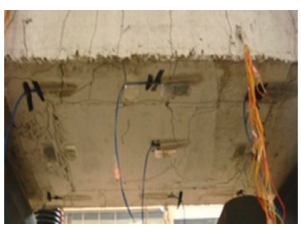

(c)

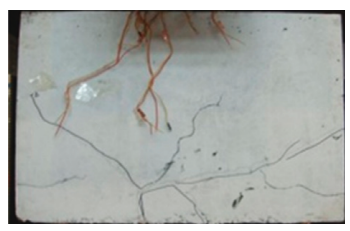

(d)

FIGURE 11: Main destruction of J-3 on the south side (a), on the north side (b), at the bottom of the specimen (c), and on the west side (d).

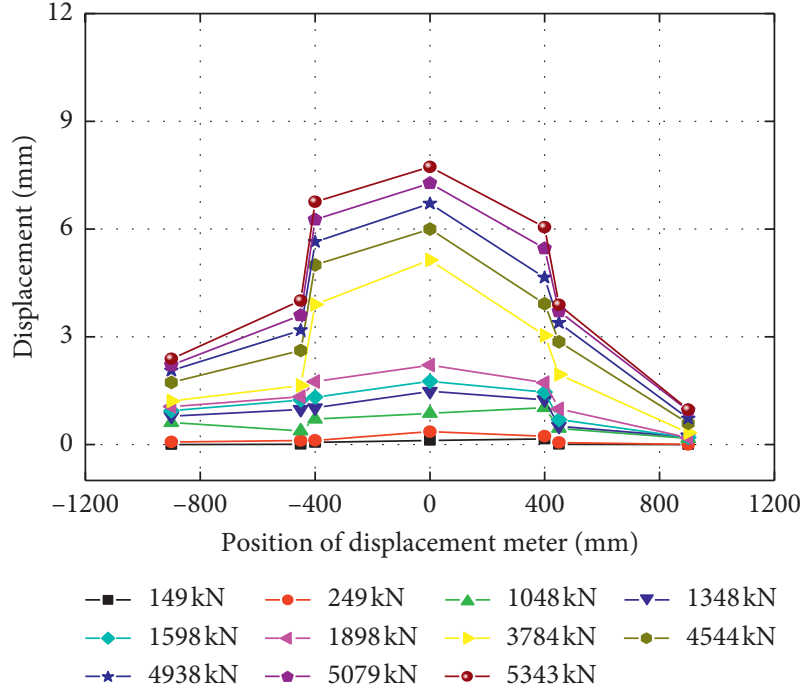

FIgURE 12: The deformation of J-1.

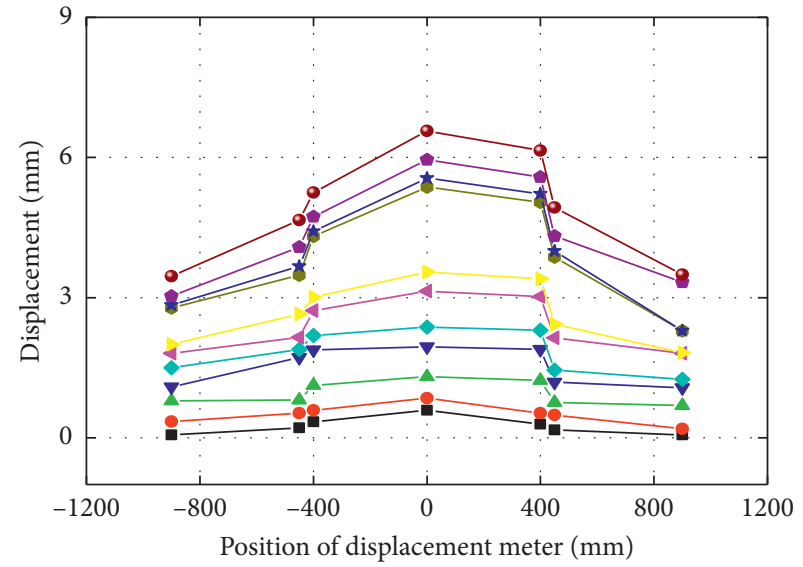

$\begin{array}{llll}-\bullet 401 \mathrm{kN} & -\bullet 801 \mathrm{kN} & -\bullet-1201 \mathrm{kN} & -\nabla-1801 \mathrm{kN} \\ -\bullet 2202 \mathrm{kN} & -280 \mathrm{kN} & -\bullet 3219 \mathrm{kN} & -\bullet 4979 \mathrm{kN} \\ -\star-5286 \mathrm{kN} & -\bullet 5609 \mathrm{kN} & -\bullet-5702 \mathrm{kN} & \end{array}$

FIgURE 13: The deformation of J-2. 


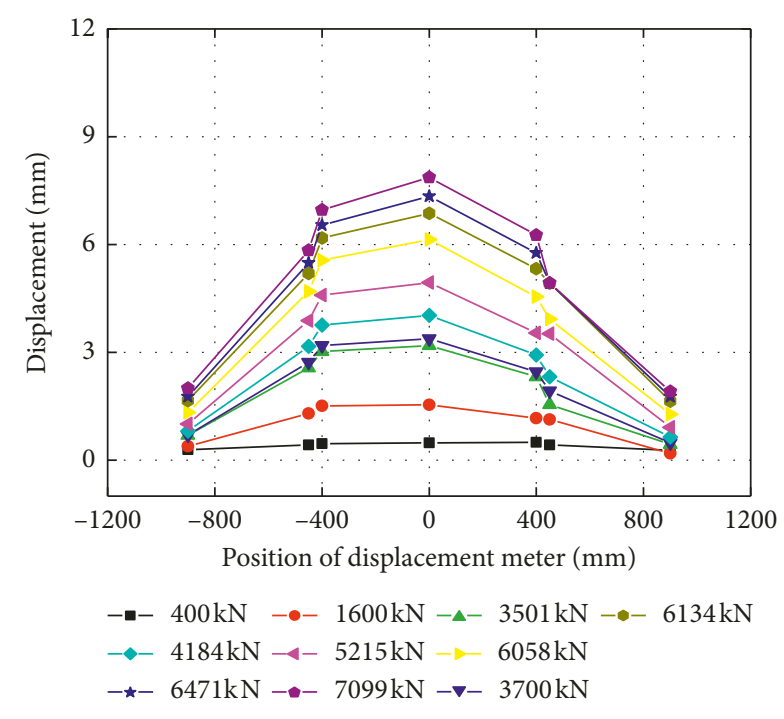

FIGURE 14: The deformation of J-3.

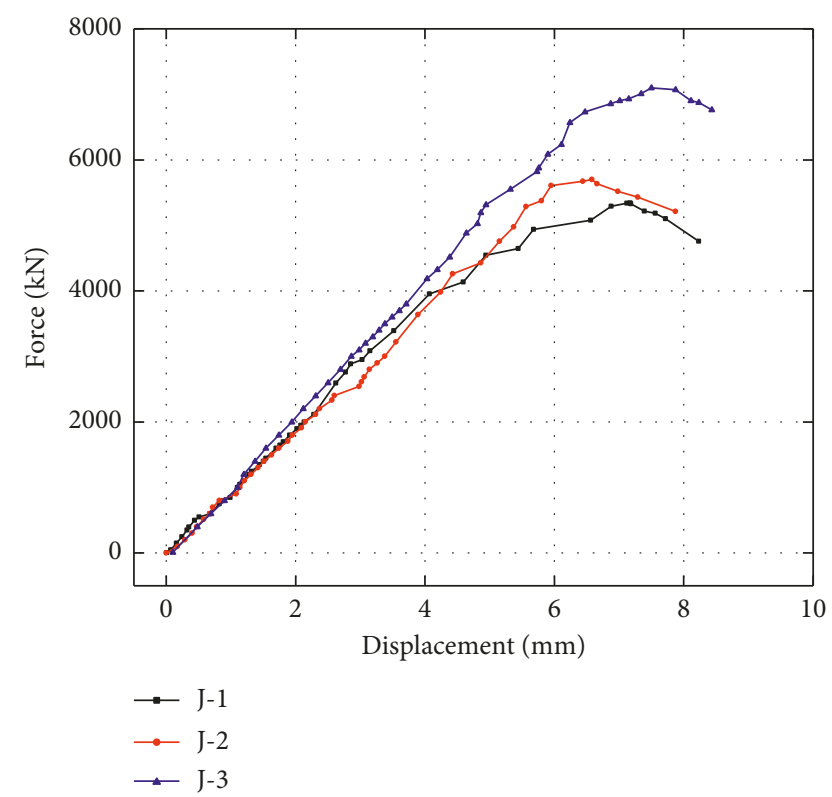

FIgURE 15: The relationship between deflection and load of specimens.

TABLE 4: Bearing capacity and failure mode of the specimen.

\begin{tabular}{lccc}
\hline Specimen & $\begin{array}{c}\text { Cracking load } \\
(\mathrm{kN})\end{array}$ & $\begin{array}{c}\text { Bearing capacity } \\
(\mathrm{kN})\end{array}$ & $\begin{array}{c}\text { Destruction } \\
\text { form }\end{array}$ \\
\hline $\mathrm{J}-1$ & 706 & 5343 & Splitting \\
$\mathrm{J}-2$ & 719 & 5706 & failure \\
$\mathrm{J}-3$ & 821 & 7098 & \\
\hline
\end{tabular}

Figure 22 shows the longitudinal bar strain curve of the $J-3$ specimen. It can be seen from the diagram that the strain rate of longitudinal reinforcement and concrete is smaller than that of concrete before $1200 \mathrm{kN}$ loading. When the load is $1200 \mathrm{kN}$, the stress of the specimen is redistributed and the change rate of the strain of the lower longitudinal

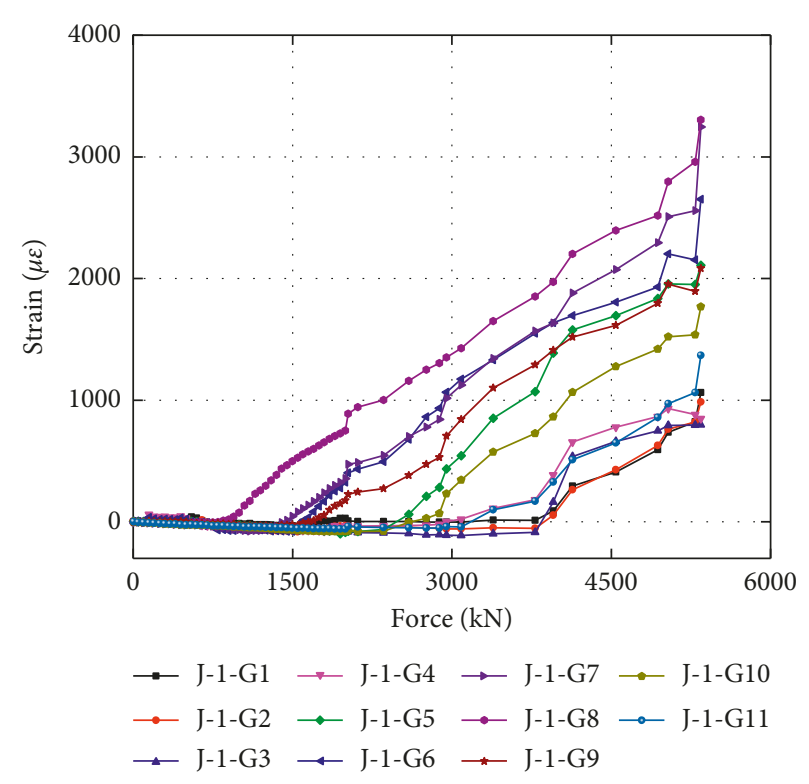

FIGURE 16: Stirrup strain curve of J-1.

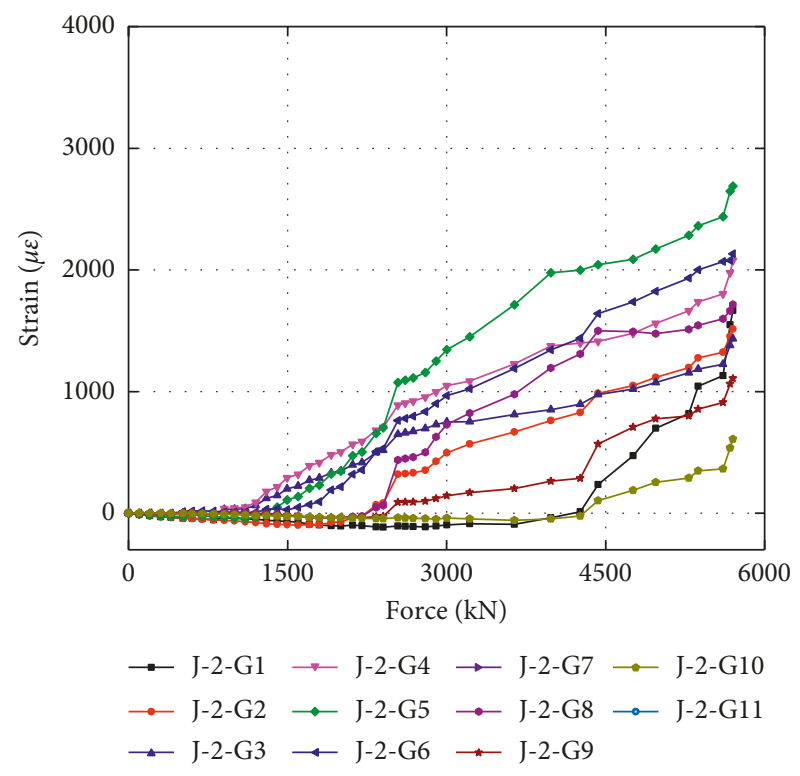

FIGURE 17: Stirrup strain curve of J-2.

reinforcement increases, which indicates that the concrete at the bottom of the specimen is cracked, the concrete near the longitudinal reinforcement is out of work, the external load is only drawn from the longitudinal reinforcement, the stress of the longitudinal reinforcement increases, and the strain increases. When the load is $4500 \mathrm{kN}$, the lower longitudinal bars yield, and the specimen is not damaged at this time.

5.5. The Formulation of Practical Theoretical Formulas for Pile Foundation Underpinning. At present, the truss-arch model is widely used in the shear calculation of concrete structures $[16,17]$. It is considered that the shear capacity of reinforced concrete structures is composed of the shear force of 


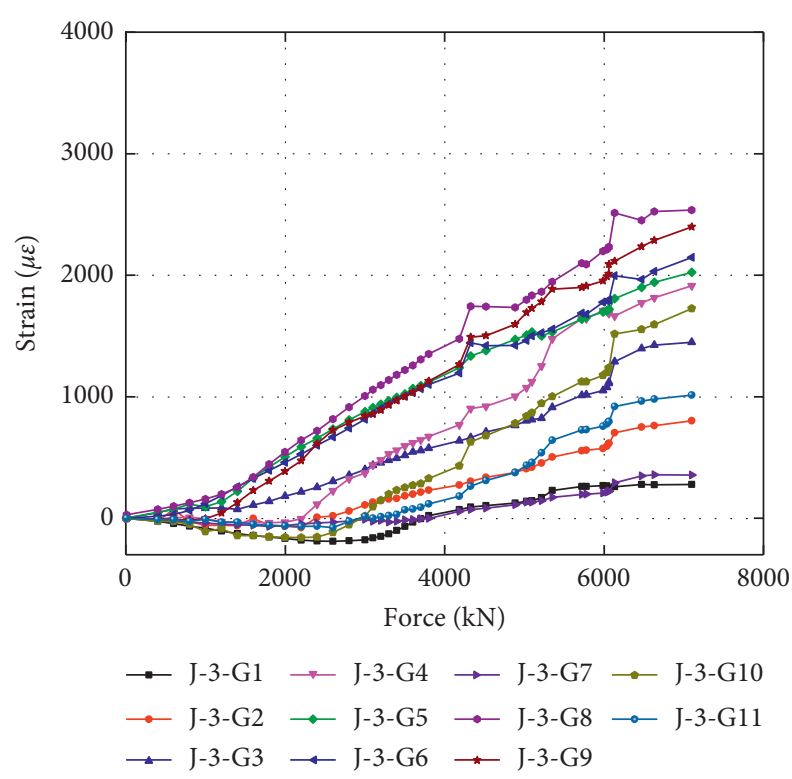

FIgURE 18: Stirrup strain curve of J-3.

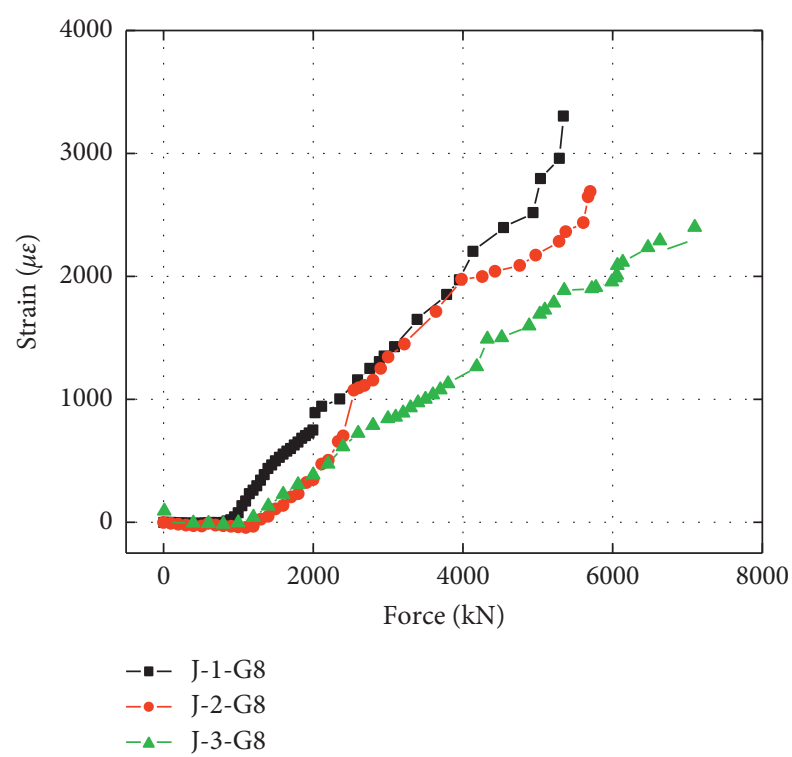

FIGURE 19: Strain curve of the first yield stirrup.

the truss tie rod, the shear force of the truss strut, and the shear force assumed by the arch [18-21]. The shear-bearing capacity of the underpinning structure can be expressed as follows:

$$
V=V_{\mathrm{t}}+V_{\mathrm{c}}+V_{\mathrm{a}} \text {, }
$$

where $V_{\mathrm{t}}$ is the shear force for the truss rod, $V_{\mathrm{c}}$ is the shear force for the concrete oblique compression bar in the truss model, and $V_{\mathrm{a}}$ is the shear force for the arch model.

According to the calculation formula of $V_{\mathrm{t}}, V_{\mathrm{c}}$, and $V_{\mathrm{a}}$, in addition to considering the yield of the planting bar, the longitudinal reinforcement, the diagonal pressure angle value, and the concrete softening coefficient are taken into consideration in the calculation of the shear model. The following formula can be obtained:

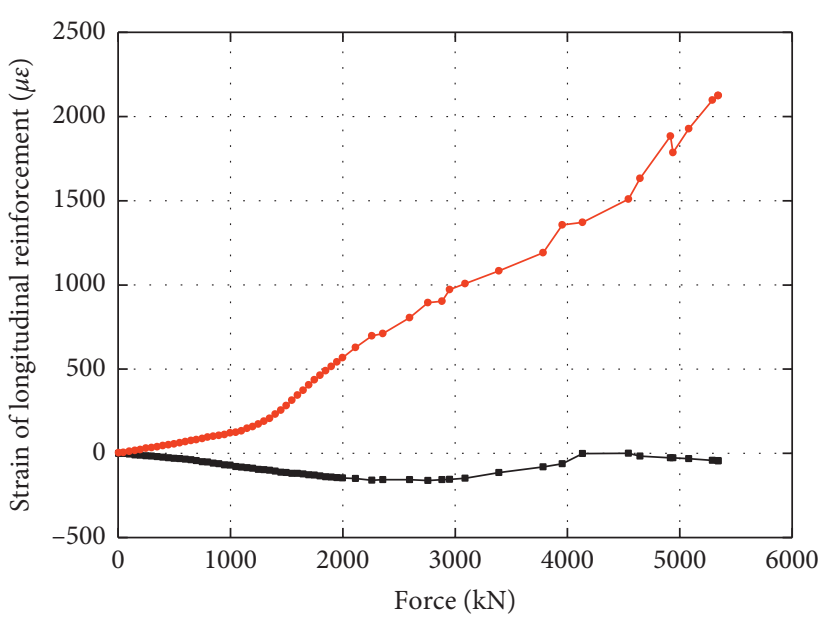

$\rightarrow$ Compressive reinforcement

- Tension reinforcement

Figure 20: Strain curve of J-1.

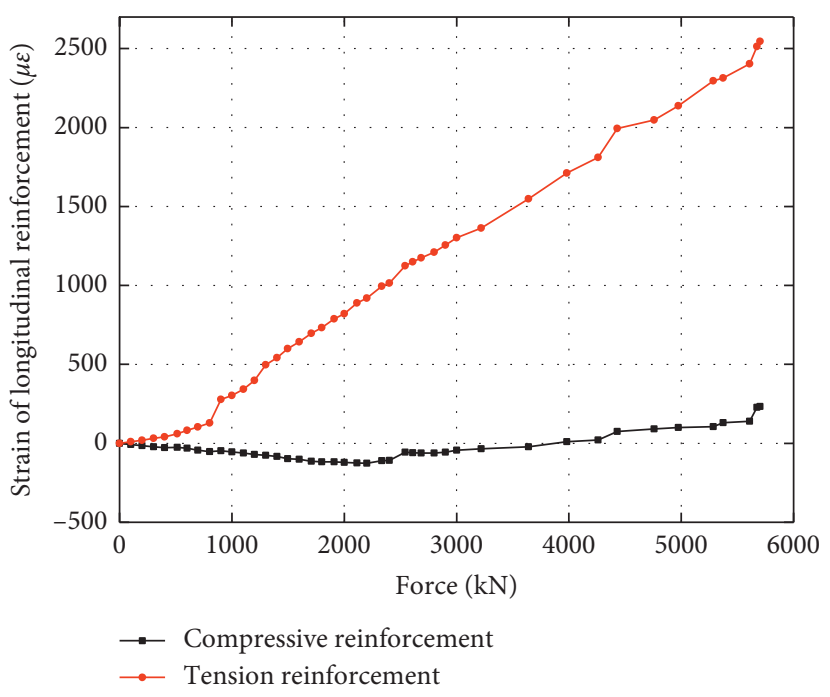

FIgURE 21: Strain curve of J-2.

$V=\rho_{\mathrm{sv}} f_{\mathrm{sv}} b_{\mathrm{e}} z \cot \alpha$

$$
\begin{aligned}
& +\left(f_{\mathrm{pt}} \rho_{\mathrm{p}} A+f_{\mathrm{t}} \rho_{\mathrm{t}} A+f_{\mathrm{et}} \rho_{\mathrm{e}} b_{\mathrm{e}} s\right)\left(\tan \alpha-0.45 \frac{\nu \delta}{\eta \cos \alpha}\right) \\
& +\frac{1}{2} \nu f_{\mathrm{c}} b h \delta,
\end{aligned}
$$

where $\rho_{\mathrm{sv}}$ is the reinforcement ratio for the stirrup; $z$ is the distance between the two longitudinal ribs in the height direction of the member's section; $f_{\mathrm{sv}}, f_{\mathrm{pt}}, f_{\mathrm{t}}$, and $f_{\text {et }}$ are the tensile strength design value of stirrups, prestressing tendons, concrete, and rebar; $b_{\mathrm{e}}$ is the effective width of the section; $\alpha$ is the angle between the tensile surface and the horizontal plane; $\rho_{\mathrm{p}}, \rho_{\mathrm{t}}$, and $\rho_{\mathrm{e}}$ are the ratio of reinforcement for the prestressed tendon, tensile steel bar, and planting bar; $\nu$ is the softening coefficient; $\delta$ is a constant related to the shear span ratio and $\alpha$; and $f_{\mathrm{c}}$ is the design value for compressive strength of concrete. 


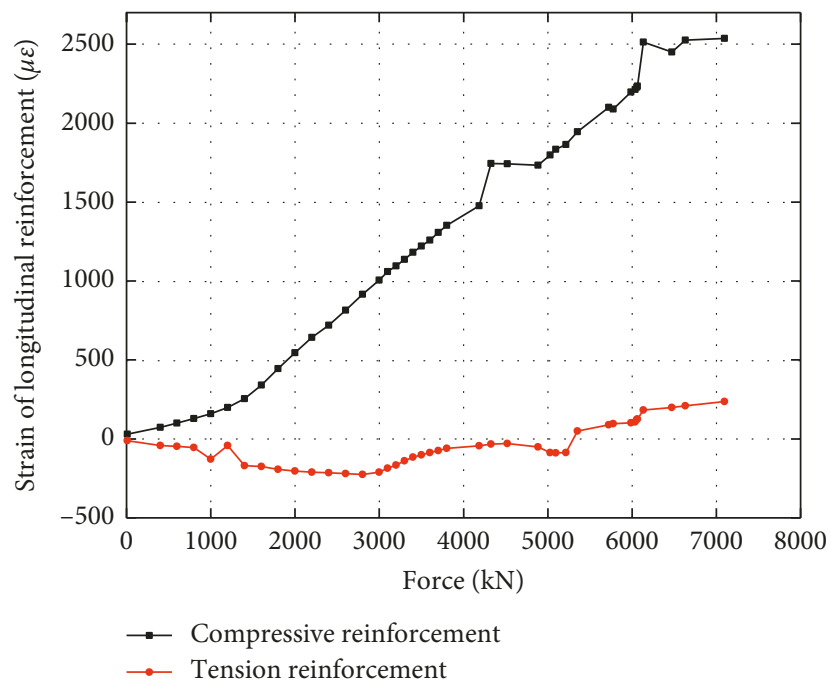

FIgURE 22: Strain curve of J-3.

In the analysis of the truss model, the angle between the concrete baroclinic bar and the horizontal axis is changed, and it is generally believed that the baroclinic angle changes $\left(26.6^{\circ} \leq \alpha \leq 45^{\circ}\right)$. In China's code, the shear force coefficient calculated by the shear capacity formula is 1 , equivalent to the 45-degree angle of the baroclinic angle. This value is partial to safety. In order to give full play to the shear effect of the stirrups and ensure that the structure has a certain margin of safety, the value of the baroclinic angle is calculated to be 38 degrees.

For the convenience of research, the concrete compressive bar is simplified as a straight compression bar in the truss-arch model. Because there are many cracks in the concrete diagonal bar, if there is a lack of restraint on the diagonal bar, it will lead to the weakening of the concrete strength, that is, the softening of concrete. Under the trussarch model, many scholars have carried out a lot of research studies on the softening phenomenon of concrete. By using the softening coefficient $v$ to reduce the strength of concrete, scholars at home and abroad have taken the reference value of the softening coefficient as follows:

$$
v=0.7-\frac{f_{\mathrm{c}}}{165}
$$

Referring to the formula and taking into account the full utilization and safety of concrete, the formula is corrected as follows:

$$
v=0.7-\frac{f_{\mathrm{c}}}{180}
$$

where $f_{\mathrm{c}}$ represents the axial compressive strength of concrete. When the softening coefficient is less than 0.5 , the softening coefficient is 0.5 .

The shear capacity of the three specimens under the theoretical formula is obtained by substituting the experimental values into Equation (2). The theoretical values and the experimental values are compared and analyzed. The contrast results are shown in Table 5 .
TABle 5: Comparison and analysis of results.

\begin{tabular}{lccc}
\hline Specimen & $\begin{array}{c}\text { Theoretical results } \\
(\mathrm{kN})\end{array}$ & $\begin{array}{c}\text { Experimental } \\
\text { results }(\mathrm{kN})\end{array}$ & $\begin{array}{c}\text { Deviation } \\
(\%)\end{array}$ \\
\hline $\mathrm{J}-1$ & 5029.7 & 5343 & 5.9 \\
$\mathrm{~J}-2$ & 5029.7 & 5706 & 11.8 \\
$\mathrm{~J}-3$ & 6201.7 & 7098 & 12.6 \\
\hline
\end{tabular}

As shown in Table 5, the deviation of theoretical calculation and experimental results is $5.9 \%, 11.8 \%$, and $12.6 \%$, respectively. The reasons for the deviation are that the actual stirrup spacing is less than the design value and the vertical infill steel bar is located at the connecting parts of new and old concrete. In order to further verify the correctness of the theoretical formula proposed in this paper, the experimental parameters of the literature [22] are taken into formulas (3-15), and the theoretical and experimental comparison is shown in Table 6.

In conclusion, the calculation formula proposed in this paper has less calculation deviation and higher reliability for the new and old concrete structure. Therefore, the formula is completely feasible in calculating the shear-bearing capacity of the underpinning structure.

\section{Conclusions}

In this paper, based on the actual project, the local $1: 1$ model experiment has been carried out on the joint connection which is in the form of "chiseling + planting bar + spray surface of building glue." The following conclusions are obtained as follows:

(1) The underpinning structure with the connection mode of "chiseling + planting bar + spray surface of building glue" has higher shear-bearing capacity, and it can meet the load-bearing capacity requirements of the structure.

(2) The hoop ratio of underpinning structures has a greater effect on the shear capacity of the structure. The higher the hoop ratio, the stronger the shear capacity. 
TABLe 6: Comparison of theoretical and experimental results.

\begin{tabular}{lcccc}
\hline Reference & Specimen & Experimental results $(\mathrm{kN})$ & Theoretical results $(\mathrm{kN})$ & Experimental results/theoretical results \\
\hline & B1 & 2300 & 2235.07 & 1.03 \\
Reference [22] & B2 & 2100 & 1992.38 & 1.05 \\
& B3 & 2100 & 2215.46 & 0.95 \\
& B4 & 2300 & 2253.93 & 1.02 \\
& B5 & 2300 & 2406.98 & 0.96 \\
\hline
\end{tabular}

(3) At the initial stage of loading, the planting bars are not involved in the work. With the increase of the load, the transverse crack is produced by the model, the reinforcement of the planting bars begins to be pulled by the tensile stress, and the dowel action is produced on the new and old concrete interface. The shear resistance of the implanted bars is assumed by the bonding shear force at the initial loading stage, the shear friction force after the interface cracking, and the dowel action.

(4) The experimental and theoretical analysis results show that the formula of shear-bearing capacity of the pile foundation underpinning structure is simple and reliable and can be applied to the calculation of the shear capacity of the new and old concrete in the underpinning structure.

\section{Data Availability}

The data used to support the findings of this study are available from the corresponding author upon request.

\section{Conflicts of Interest}

The authors declare that they have no conflicts of interest.

\section{Authors' Contributions}

Lei Yan and Gang Wang equally contributed to the work.

\section{Acknowledgments}

The research presented herein was supported by the $\mathrm{Na}$ tional Natural Science Foundation of China (No. 51508453), Science and Technology Research Project of Chongqing Municipal Education Commission (No. KJQN201801223), 2011 Collaborative Innovation Center of Chongqing, Natural Science Foundation Project Chongqing CSTC (cstc2018jcyjAX0360, 2015jcyjA00022, and 2017jcyjAX0085), Technological Innovation and Demonstration Project of Chongqing Municipal Science and Technology Commission (cstc2018jscx-msyb0517), Innovation Team Construction Project of Chongqing (No. CXTDX201601034), Project of Disaster Prevention, Reduction and Safety Innovation Team of Engineering Structure in Three Gorges Reservoir Area of Chongqing Three Gorges University, and Project of Chongqing Three Gorges University (17ZP08, 17RC06, and 17ZZ03).

\section{References}

[1] Y. Masuda, T. Minoshima, and H. Makino, "Large-scale underpinning for an underground urban railway station," Tunnelling and Underground Space Technology, vol. 7, no. 2, pp. 133-140, 1992.

[2] J. R. Davie and H. Senapathy, "Underpinning a 3000-ton structure with high-capacity mini-piles," in Proceedings of International Deep Foundations Congress, pp. 647-654, Orlando, FL, USA, Februery 2002.

[3] R. P. Stulgis, B. E. Barry, and F. S. Harvey, "Foundation underpinning with mini-piles: "A first" in Guyana, south America," in Proceedings of Geosupport Conference, pp. 700711, Orlando, FL, USA, January 2004.

[4] D. Jing, S. Cao, and H. Guo, "Application of steel platemasonry composite structure technology for underpinning of masonry walls," China Civil Engineering Journal, vol. 42, no. 5, pp. 55-60, 2009.

[5] M. S. Robison, "Excavation support and micropile underpinning in Vail, Colorado," in Proceedings of Biennial Geotechnical Seminar, pp. 112-118, Denver, CO, USA, November 2010.

[6] H. F. Shan, F. Yu, T. D. Xia et al., "Performance of the underpinning piles for basement-supplementing retrofit of a constructed building," Journal of Performance of Constructed Facilities, vol. 31, no. 4, article 04017017, 2017.

[7] S. Wang, S. Duan, and J. Cao, "Dynamic analysis of pile foundation underpinning structure," Journal of Shijiazhuang Railway Institute (Natural Science Edition), vol. 22, no. 3, pp. 53-56, 2009.

[8] J. Bi, Pile Foundation Underpinning Technology in Subway Construction, Shijiazhuang Railway University, Shijiazhuang, China, 2007.

[9] J. Yu, Numerical Analysis of Load Transfer Law and Deformation Characteristics of Pile Girder Underpinning in Jing Chang, Shandong Jianzhu University, Ji'nan, China, 2013.

[10] O. Ochi, H. Kunotsubo, S. Nishino et al., "Underpinning and large underground excavation work at Kyoto subway Tozai line-misasagi station works," Journal of Tunnel Engineering JSCE, vol. 6, pp. 315-320, 2011.

[11] T. Onuki, K. Gima, and M. Matsuoka, "Design and construction planning for the keage underground station on the kyoto tozai line," Journal of Tunnel Engineering JSCE, vol. 1, pp. 281-286, 2011.

[12] Z. Peng, Design Calculation and Construction of Underpinning Project, China University of Geosciences Press, Wuhan, China, 1997.

[13] J. Bu, Research and Application of Key Technology of Bridge Pier and Column Active Underpinning Under Vehicle Dynamic Load, China Academy of Railway Science, Beijing, China, 2010. 
[14] S. Ye, Underpinning Technology: Foundation Reinforcement for Existing Buildings, China Railway Publishing House, Beijing, China, 1991.

[15] J. Pan, Z. He, and S. Zhou, "Pile underpinning technology for bao'an overpass of shenzhen Metro line 5," Urban Rail Transit Research, vol. 9, pp. 94-97, 2011.

[16] X. Li, H. Wang, Q. Zhou et al., "Impact on regularity of track from pile underpinning of light railway bridge," in Proceedings of International Conference of Chinese Transportation Professionals, pp. 1-9, Harbin, China, August 2009.

[17] J. Han and S. L. Ye, "A field study on the behavior of a foundation underpinned by micropile," Canadian Geotechnical Journal, vol. 43, no. 1, pp. 30-42, 2006.

[18] W. E. Kamash, "Numerical analysis of existing foundations underpinned by micropiles," International Journal of Geomechanics, vol. 17, no. 6, 2016.

[19] M. Georgiadis and C. Anagnostopoulos, "Design of underpinning piles to control monument settlement," Therapie, vol. 68, no. 4, pp. 201-208, 1998.

[20] M. Haghbin, "Study on behavior of soil reinforcing pile in piled raft systems," International Journal of Civil Engineering, vol. 12, no. 4B, pp. 304-315, 2014.

[21] T. Guo, A. Li, L. Wei et al., "Horizontal translocation of a high-rise building: case study," Journal of Performance of Constructed Facilities, vol. 27, no. 3, pp. 235-243, 2013.

[22] Z. Zhang, X. Huang, and Y. Zhang, "Experimental study on interface connection between new and old concrete," Journal of South China University of Technology, vol. 28, no. 10, pp. 81-86, 2000. 


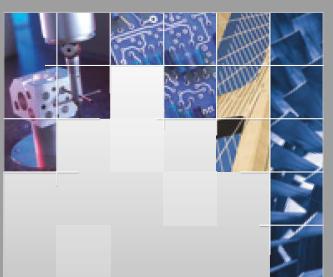

\section{Enfincering}
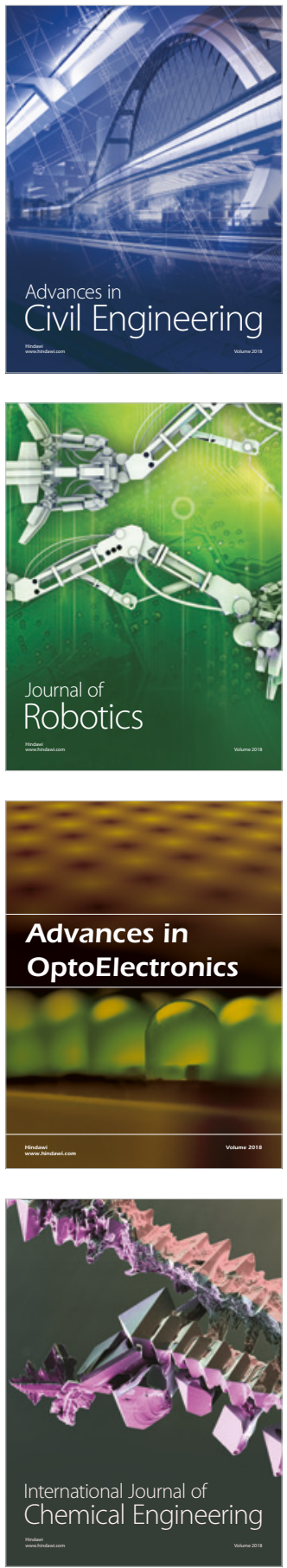

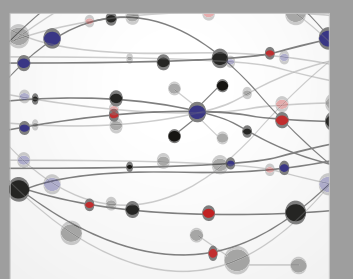

\section{Rotating \\ Machinery}

The Scientific World Journal

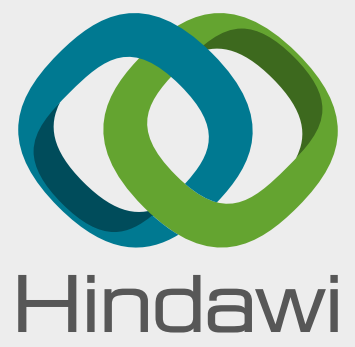

Submit your manuscripts at

www.hindawi.com
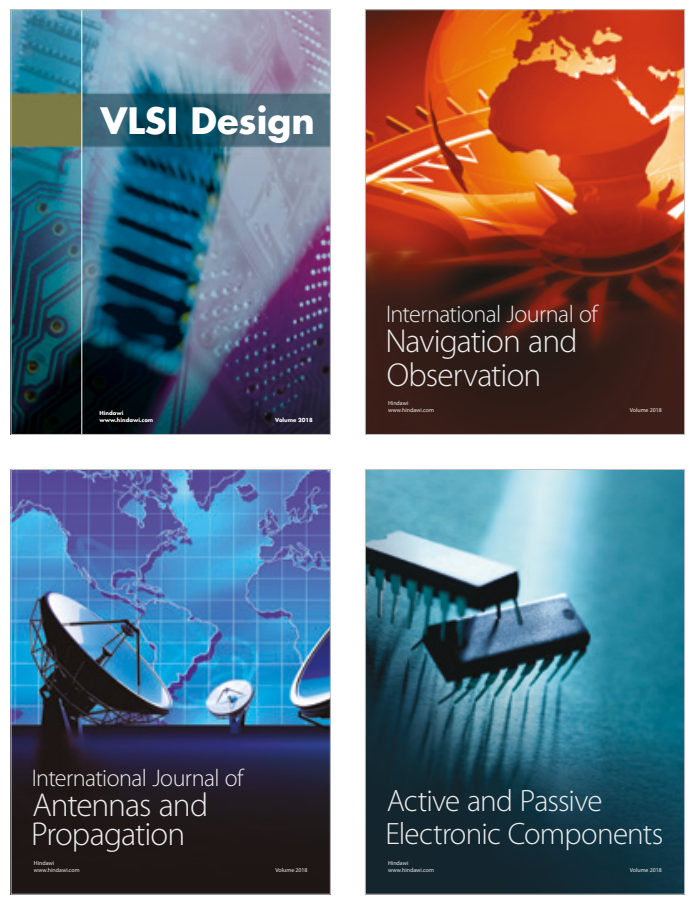
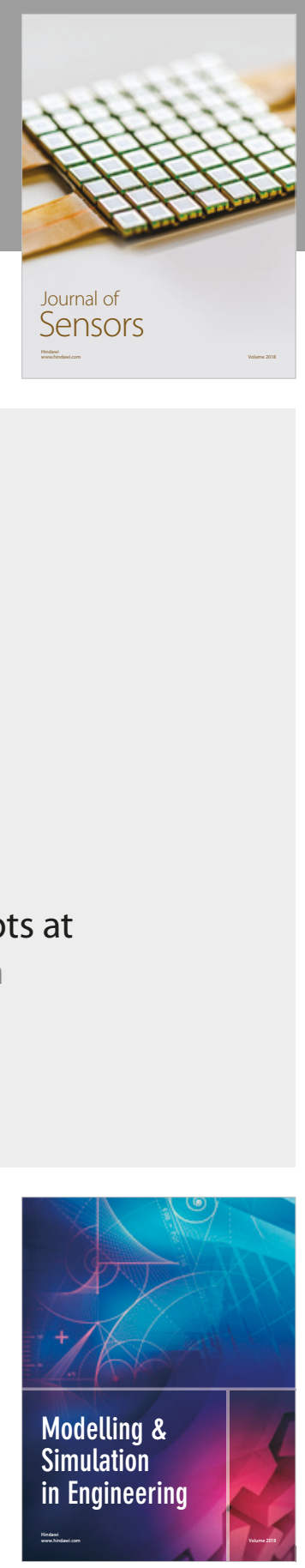

\section{Advances \\ Multimedia}
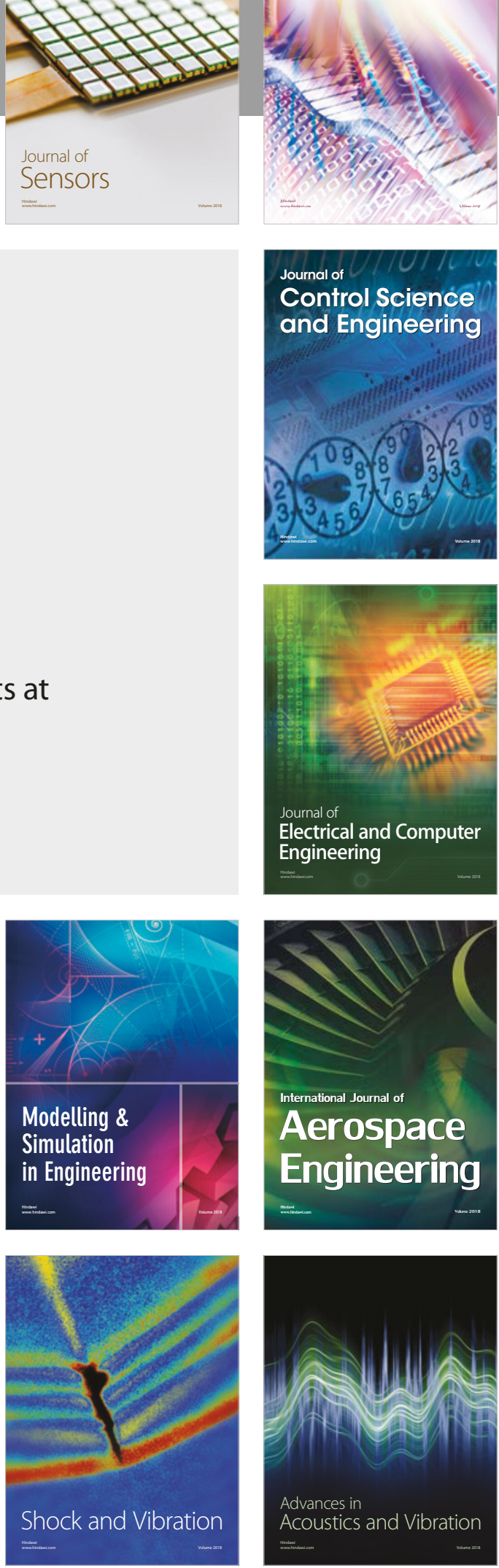